\title{
Фразеологічні інновації української мови в медіалінгвістичному висвітленні*
}

\author{
ДМИТРО СИЗОНОВ \\ Кафедра стилістики та мовної комунікації Київського національного університету \\ імені Тараса Шевченка, бул. Т. Шевченка, 14, UA-01601 Київ \\ Dmytro SYzONOV, Department of Stylistics and Language Communication, \\ Kyiv National Taras Shevchenko University \\ E-mail:dm_sizonov@ukr.net
}

(Received: 7 July 2018; accepted: 14 September 2018)

\begin{abstract}
This paper focuses on interpretations of the term phraseological innovations or new phraseology. According to international stylistics, the latter are considered fixed linguistic units of idiomatic nature. The author presents the main conceptions of research targeting new phraseological units, and reviews the main sources of origin of new phraseological constructs, particularly those which are related to mass media. Conditions of functioning of new media phraseological units as sociopolitical, ethnographic, cultural, and educational markers are also considered. New phraseological constructs are analyzed in the scope of functional, stylistic, cognitive, and psycholinguistic aspects, which proves the topicality of this field of linguistic research. Particular focus is made on extralingual and intralingual factors causing creation of new phraseological units. Conditions stimulating wider use of phraseology in the mass media and its influence on Ukrainian language evolution are investigated in the paper.
\end{abstract}

Keywords: phraseology, Ukrainian, phraseological innovations, media language

\section{1. Медійна фразеологія у функціонально-стилістичному аспекті (огляд сучасної літератури)}

У сучасній медіалінгвістиці останнім часом особлива увага приділяється стилістичному аналізу мовного ресурсу й аналітичному опису мовних інтенцій, що впливають на потенційного реципієнта. Про актуальність дослідження фразеологічного рівня в різних видах комунікації лінгвісти почали говорити ще в XX ст. Опис активного впливу масової комунікації та їх стилістичного ресурсу на сучасні слов'янські мови була однією $з$ домінантних тем у засіданнях Стилістичної комісії при Міжнародному комітеті славістів у 2013 р. Особливу роль процесі оновлення лексико-фразеологічного фонду

* Автор висловлює подяку Заслуженому діячу науки та техніки України, доктору філологічних наук, професору Київського національного університету імені Тараса Шевченка, завідувачу кафедри стилістики та мовної комунікації, Заступнику голови Комітету славістів України, члену медіалінгвістичної комісії Л. І. Шевченко за компетентну підтримку, підготовку матеріалів до друку, а також за фахові поради при описі матеріалу в новому лінгвістичному аспекті. 
сучасних слов'янських мов відіграє нова медійна фразеологія - науковий акцент ставили члени Медіалінгвістичної комісії при Міжнародному комітеті славістів у 2013 p.

Тому фактично відбувся зсув наукових поглядів на фразеологізм: розширились функції фразеологізма і він вийшов за межі художнього функціонального стилю і почав аналізуватися не тільки як стале словосполучення народно-поетичного чи літературного походження.

Новаторство в лексичних системах слов'янських мов стало особливо актуальним саме в XXI ст. (ТАРАНЕнко 2002: 33), що пояснюється небаченими раніше темпами оновлення мови, зокрема її словникового складу, концепціями мовної економії, мовного імпералізу (передусім, широким впливом англійської мови), вкраплення позалітературних мовних елементів та ін. Українська мова поряд з іншими слов'янськи мовами, зокрема білоруською, болгарською, угорською, польською, російською та ін., переживає на сучасному етапі активний розвиток неології в розрізі всіх мовних рівнів, викликаний прискоренням темпів суспільного життя, зростанням політичної активності мас, динамікою розвитку інформаційного поля (передусім завдяки Інтернеткомунікації), стрімким науково-технічним прогресом, що актуалізує пошук нових слів та значень, які активно входять в обіг мови слов'ян. Слушно з цього приводу зауважує польський дослідник С. Гайда:

В актуальні задачі сьогодення входить зріз мовних змін, що відбуваються в усіх функціональних сферах, де поява нового стилістичного ресурсу сигналізує про початок нової ери вербалізації суспільства вже в XXI ст. Фонд лексичний і фразеологічний постійно змінюється, що говорить про динаміку розвитку літературних мов сучасності (ГАйДА 2015: 11).

Не можемо не згадати в цьому контексті теорію інтелектуалізації мови, де слідом за світовими науковцями Ф. Гегелем (діалектика інтелектуального та мовної свідомості), Р. Якобсоном (протиставлення «частина - ціле» в потоці мовлення), 3. Шаляпіною (теорія розширеної стратифікації моделювання мовної компетенції), професор Київського університету Л. Шевченко наголошує:

Все більшої ваги набуває в мовознавстві аналіз, що спирається на розуміння мови (та іiі нового лексичного складу) через суспільні функції, реалії життя, домінантність Інтернет-комунікації над іншими традиційними формами. Відповідно, в розмовному та медійному (стилі масової інформації) стилях відбувається постійний інтелектуальних рух мовних універсалій (Шевченко 2001: 39).

Саме мас-медіа, на нашу думку, найактивніше реагують на всі репрезентативні інновації в різноманітних сферах людської діяльності, що відповідно вербально реалізується в мові (про це зазначали ще у XX ст. І. Білодід, В. Русанівський, Д. Баранник та ін.). На сучасному етапі знання про фразеологічні інновації в різних сферах суспільної комунікації, зокрема медійній, говорять 
у своїх роботах українські вчені - О. Стишов, О. Тараненко, Л. Пашинська та ін.; серія статей про неофразеологію, що твориться в українському медіапросторі, вийшла й у міжнародних наукових збірниках - польському «Stylistyka» (див. Сизонов 2015a), українському «Актуальні проблеми української лінгвістики: теорія і практика», російському «Медиалингвистика» та ін. (див. Сизонов 2015b); окремі публікації вийшли в угорському виданні «Studia Slavica Hung.» (див. DZIEwoŃSKA-KISS-RÁDUly 2014: 307); серія монографічних видань вийшла в Україні, Росії, Польщі, Угорщині та ін. країнах славістичного світу.

Про фразеологію в публіцистиці (беремо ширше - в мас-медіа) говорив ще в середині XX ст. відомий славіст Г. Винокур, який наголошував на фразеологізації газетно-журнальної комунікації (див. Винокур 1959). В еволюції наукової думки лінгвісти врахували думки попередніх поколінь науковців, щоправда уточнивши мету та завдання сучасної комунікації та тим самим наголосивши на дещо іншому (функціонально-комунікативному) аспекті при розгляді фразеологізма. Тому доречним вважаємо подати сучасні розуміння медійного фразеологізма (або ж фразеологізма у мові 3МI) авторами-медіалінгвістами XXI ст.

О. Стишов на основі медійного дискурсу показує розвиток мови та іiі одиниць (слів та словосполучень). Він доводить, що нові слова виникають саме в текстах стилю масової інформації, адже ЗМІ $є$ індикатором актуальних подій, що відбуваються в соціумі. Нові слова він називає медійними неолексемами, а нові фразеологізми - медійними неофраземами (наприклад, тіньова економіка, чорний ринок, любі друзі, бандитам - тюрми та ін.) (див. Стишов 2003).

Л. Дускаєва тлумачить фразеологізм у медіа як певну експресивну універсалію, що надає медійному тексту додаткової емоційності: це один із найяскравіших і дієвих лексичних одиниць в мас-медіа, метою використання якого $є$ емоційний вплив на реципієнта. Метафоричність, конотативність, експресивність - всі ці якості фразеологічних одиниць надають мові ЗМІ образності та виразності, а сама ця мовна одиниця у медійній мові набуває нових відтінків у значенні та може активно вживатися як прямо, так і трансформовано (див. ДусКАЕВА 2010).

С. Квіт у праці «Масові комунікації» особливу роль відводить сталим словосполученням - медіафраземам. Як мовні одиниці вони $є$ елементом медійної технології, можуть бути основою мовної гри, мовного каламбуру, в паблік-релейшнз (PR) та рекламі - фразеологізми можуть бути основою для т. зв. «рекламного гіпнозу», а в політичному дискурсі вони є основою для гасел та промов (див. КвІт 2008).

А. Чудінов наголошує про політичну метафору та політичний фразеологізм (інноваційний фразеологізм). Гасла як титульні ідеї та рекламні слогани як сталі словосполучення політичних партій - це теж фразеологія, яка за допомогою ЗМІ активно тиражується в політичних текстах: «В борьбе обретешь ты право свое», «Пролетарии всех стран объединяйтесь!», «Пока мы 
едины - мы не победимы», «Россия для русских» (3 політичних гасел та промов російського політикуму) (див. Чудинов 2010).

Г. Почепцов вказує на роль концептів, що утворюються за допомогою клішованих мовних одиниць, мовних стандартів та фразеологізмів уживатись як «мовна зброя в інформаційній війні» (власне, автор доводить відомий постулат, що словом можна вбити, а якщо це два чи три слова, що мають одну зв'язну семантику (фразеологізм у медіа), то таке вже сполучення вважається «зброєю повільної дії») (див. Почепцов 2008).

У світовій практиці, зокрема в польській медійній лінгвістиці (див. праці польських дослідників: БоголЕБскА 2010, WoRSOWICZ 2013 та ін.), в останні десятиліття акцентується увага на прикладному аспекті медіалінгвістики, яка повинна займатися не лише лінгвістичним аналізом медіадискурсу, але i створювати практичні рекомендації для медіатворчості (від лексеми, словосполучення, фрази до цілого тексту / дискурсу). Цікаво, що дослідники німецької медіалінгвістичної школи (PERRIN 2006) наголошують на особливій ролі нових одиниць: вони (нові мовні одиниці) виступають вербальним «відбитком» реальної ситуації в суспільстві і показують динамізм літературної мови. Дотримуємося сучасної наукової традиції медіалінгвістів Свропи і ми, акцентуючи увагу на детальному функціональному аналізі нових мовних одиниць (зокрема фразеологізмів) в українському медіапросторі та їх впливі на масову свідомість.

Отже, і ми спробуємо визначити наукове поле термінопоняття «медійний фразеологізм» 3 урахуванням синкретизму наук про мову (закцентуємо на двоєдності понять «мова - медіа») та стрімкого розвитку в цьому ключі медіалінгвістики:

1) Поняття «фразеологізм» (в медіа) ми розуміємо як певну експресивну універсалію, що надає мас-медійному тексту додаткової емоційності.

2) Виводячи в наукову площину дефініцію медійний фразеологізм ми враховували передусім екстралінгвістичні фактори розвитку 3МІ (на «соціальній оцінності» медійної мови наголошує С. Гайда, на «спонукальність медіа» вказують російські дослідники Г. Солганик, М. Кожина; про «оцінку в медіа» кажуть українські вчені Л. Шевченко, О. Стишов та ін.).

3) Фразеологізм у масовій комунікації, за визначенням авторів першого в Україні словника «Медіалінгвістика» (див. Шевченко 2014: 180) є однією 3 найяскравіших і дієвих лексичних одиниць в 3МI, метою використання якої $\epsilon$ емоційний вплив на реципієнта. Головними якостями фразеологічних одиниць, на доречне переконання сучасних медіалінгвістів, $\epsilon$ експресивність, конотативність та метафоричність, що надають мові 3МІ образності та увиразнення, а сам фразеологізм у медійній мові набуває нових відтінків у значенні й може активно використовуватися як з первинною (прямою), так $\mathrm{i}$ трансформованою (вторинною) семантикою. 


\section{2. Медійна база наукового дослідження}

Проводячи дослідження (2015-2016 рр.), ми спочатку вибрали різноаспектні (за тематикою і віковим принципом) та поліжанрові (друковані й електронні) засоби масової комунікації. Для аналізу нами взяті по три телевізійних канали загальнонаціонального (ТРК «Україна», «СТБ», «1+1») та регіонального (ТРК «Київ», «АТН» м. Харкова, «Zik» м. Львова) значення, інформаційні програми «Факти» (телеканал «ICTV»), «Новини № 1» (телеканал «112.Україна»), «Час новин» («5 канал»), інформаційно-розважальні програми «ТСН. Особливе» (телеканал «1+1»), «Люди. Hard Talk» (телеканал «112. Україна»), «EmOneNews» (телеканал «м1»). Також для аналізу були взяті три друковані видання загальнонаціонального («Газета по-українськи», «Дзеркало тижня», «День») та регіонального («Деловая столица», «Вечерний Харьков», «Галицькі контракти») значення. При аналізі враховувались інтернетпортали ділової та економічної тематики, зокрема «Кореспондент» (http:// korrespondent.net), «Бізнес» (http://businessua.com), «Экономические известия» (http://eizvestia.com), а також інформаційно-аналітичні портали інформагенцій «Укрінформ», «Уніан», «Українська правда», радіостанцій «Голос столиці», «Радіо Київ» та «Наше радіо». Для порівняння стилістичних функцій фразеологічних одиниць ми використовували зібрані нами медійні матеріали 2012-2015 років, щоб унаочнити та більш коректно подати наукові дані. ${ }^{1}$

\section{3. Методи дослідження}

Основними методами дослідження медіатекстів, які нами використовувалися для аналізу медійної фразеології, були метод прагмалінгвістичних моніторингу (ДоБРосклонскАя 2008), що пов'язує його з безперервним збором інформації в різних джерелах за певний відрізок часу), метод критичного аналізу медіатексту (за допомогою даного методу в контексті соціально-політичних перетворень аналізувалися фразеологічні одиниці в різних текстах 3MI; деякі дослідники акцентують увагу на критичному зіставленні різних типів мовних одиниць (для нас важливою $є$ медійна фразеологія, яка може зіставлятися з різними типами літературної фразеології при описі жанрового синкретизму в медіа), метод дискурс-аналізу (полягає в ідентифікації та підрахунках мовних одиниць, які використовуються в певному медіатексті й включає в себе елементи статистичного підрахунку і тим самим дозволяє медіалінгвісту максимально об'єктивно дослідити сферу 3МІ в контексті медіакартини світу), метод лінгвокультурного аналізу в медіа (дозволив нам дослідити медійну фразеологію в контексті розвитку мов і культур інших країн) та ін.

${ }^{1}$ Подані приклади відбирались для унаочнення доказової бази. Ми не намагалися подати всі знайдені контексти, а лише продемонстрували типові з них. Тут і далі подається лише частина контекстів, знайдених в українських 3МІ за зазначений період. 


\section{4. Мас-медіа як джерело фразеологічних інновацій}

В українському мас-медійному просторі спостерігається тенденція до використання неологічних одиниць (від слів до стійких словосполучень) в різних медіасферах - від традиційних (друкованих) до інноваційних (електронних). Як відомо, характерною особливістю ЗМІ $є$ соціальна оцінність, а одним із головних засобів, що реалізують ії у медійному дискурсі, - фразеологізми.

4.1. За нашими спостереженнями нові фразеологізми в українських ЗМІ виникають на тлі широких екстралінгвістичних чинників, зокрема:

1) глобальних процесів у суспільстві (політичних, економічних, культурних та ін.) та логічною появою фразеологізмів у кожній сфері суспільної діяльності;

2) розширення кордону комунікативно-інформаційного поля, основні функції якого передбачають не тільки інформування, але і вплив на масову мовну свідомість (досягнення цього ефекту за допомогою фразеології очевидна);

3) полікультурності, яка впливає на формування принципово нового лексико-фразеологічного фонду (тут важливо наголосити на теорії мовного імпералізму; ${ }^{2}$

4) розширення інформаційного простору різних сфер людського буття;

5) поширення явища т. зв. мовної моди - вживання в мові різних ЗМІ (від друкованих до електронних) нових лексем та фразеологічних одиниць, які використовуються в нових інформаційних реаліях з оновленою семантикою і функціями.

4.2. Серед інтралінгвістичних чинників, що впливають на розвиток лексико-семантичної системи мови сучасних мас-медіа та появу нової фразеології у мові ЗМІ, ми виділяємо:

1) мовну естетизацію, що полягає у забарвленні лексичних одиниць додатковими відтінками та значеннями (фразеологія як ментальний код слугує естетизацією власне українського медійного тексту);

2) специфічність стилістичних норм, властивих стилю масової інформації (очевидно, це підштовхує авторів шукати нові мовні тактики для опису реалій, залучаючи широку палітру фразеологіі);

3) свідоме тиражування вдалих словесних каламбурів, авторських неологізмів, номінацій, крилатих висловів, фразеологізмів народно-поетичного та літературного походження, медіафразеологізмів;

4) функціонування нетипових для мови ЗМІ складних синтаксичних конструкцій, описових зворотів та ін., що сприяє використання в медіакомунікації сталих словосполучень (фразеологізмів);

${ }^{2}$ Теорія мовного імпералізму пов'язана 3 працями англійського вченого Р. Філіпсона («linguistic imperialism»). Домінантною мовою у світі дослідник називає англійську, як панівну. Українська масова комунікація не $є$ виключенням і так само піддалась впливу англійської мови, що виявлено в оновленні лексико-фразеологічного фонду, насиченого англіцизмами. 
5) розповсюдження норм розмовного стилю в медіамовленні, що особливо виявляється в Інтернет-комунікації, блогах та форумах з використанням нових лексико-фразеологічних ресурсів;

6) мовна експресія, що виявляється у використанні емоційно-забарвлених мовних одиниць, стилістичних фігур та тропів (експресія досягається і використанням фразеологічних одиниць, які ії всіляко підсилюють);

7) оцінна номінація та стилістична конотація (фразеологія в цьому контексті слугує засобом влучної інформаційної номінації та слугує певним смисловим центром);

8) мовна економія, що виявляється у пошуках більш вдалих (коротких) мовних конструкцій, що відповідає сучасній медійній комунікації - просто і доступно доносити думку реципієнту);

9) тенденція до стирання меж між функціональними стилями. Так, наприклад, сучасний медіадискурс складається з елементів не тільки стилю масової інформації, а й розмовного, наукового, художнього та інших стилів. Саме тому фразеологія займає важливу нішу в мовно-стилістичному плані, бо іiі ресурс безмежно широкий.

4.3. Засоби масової інформації виступають, як відомо, дзеркалом актуальних подій сучасності. Мовний матеріал, зокрема й фразеологія, що тиражується у 3MI, фактично є його інструментом, певним маркером в описі подій та явищ. Тому медіа, без перебільшення, вважається головним джерелом нових слів та словосполучень. Такими джерелами нових фразеологізмів, враховуючи наш зібраний матеріал, $\epsilon$ :

1) власне засоби масової інформації (друковані, електронні медійні тексти): політичні переслідування; тіньова економіка; Свропейське (світле) майбутнє; чорний долар; диктаторські закони; ляшкові будні; на городі Бузина, а в Києві Кличко;

2) рекламні тексти та гасла: «Не гальмуй - снікерсуй»; «Я це люблю»; «Солодкий знак якості», «Об’єднані футболом»;

3) політичні рекламні тексти (передвиборча кампанія): «Вона - працює» (про Ю. Тимошенко); «Сильний Президент - сильна країна»;

4) політичні рекламні слогани: «Разом нас багато»; «Схід і Захід - разом!» (Помаранчева революція, 2004 р.); «Ми - є»; «Україна - це Європа!» («Революція гідності», 2014 р.); «Україна для людей», «Голосую за українське», «Захистимо українське село» (з рекламних передвиборчих гасел);

5) крилаті вислови відомих діячів культури, мистецтва, кіно, телебачення: «Де правди шукати, коли брат на брата» (А. Кузьменко, лідер музичної групи «Скрябін»); «Я не хочу бути героєм України - Не цінує героїв моя країна!» (С. Положинський, лідер музичної групи «Тартак»); «Я не здамся без бою» (С. Вакарчук, лідер музичної групи «Океан Ельзи»); «Нації вмирають не від інфаркту» (Л. Костенко); «Як добре те, що смерті не боюсь я» (В. Стус).

6) крилаті вислови з мови політиків: «Маємо те, що маємо» (Л. Кравчук); «Любі друзі»; «Ці руки нічого не крали»; «Бандитам - тюрми» (В. Ющенко); «Якщо куля в лоб, то куля в лоб» (А. Яценюк) та ін. 
Отже, фразеологічні одиниці, за нашим фаховими спостереженням, виникають в мас-медіа та активно тиражуються, ураховуючи екстра- й інтралінгвістичні особливості. Медійні фразеологізми допомагають авторам текстів 3МІ створювати комплексне уявлення про реальність завдяки впливу на реципієнта, образному узагальненню та емоційному опису навколишньої дійсності. Саме виразові особливості фразеологізмів спираються на високий ступінь узагальненості значення, наявність стилістичної забарвленості й образність, на експресивну наповненість, що, у свою чергу, зумовлює широкі можливості їх використання фразеологізмів у мові масової української комунікації.

\section{5. Стилістичні функції фразеологічних інновацій у мас-медіа}

Український медіапростір, який сьогодні стрімко розвивається, насичений різними фразеологізмами - традиційними та новими, що виникають відповідно до вимог часу та мають тенденцію активного тиражування соціумом. Саме тому в мас-медіа не можуть функціонувати фразеологізми, що не відомі сучасному реципієнту чи не актуальні в певний час у певній ситуації. До того ж, самі фразеологізми можуть бути актуальні відповідно до актуальної ситуації (музичної, спортивної, політичної, економічної та ін.): «,Scorpions“ знову на сцені, а фани - на сьомому небі від щастя» («Газета по-українськи», 27.12.2012), «Рибка після повернення у «Динамо» на сьомому небі від щастя» («5 канал», 10.08.2013), «На сьомому небі від щастя: Луценко вже на волі» (ТРК «У країна», 07.04.2013), «3 коливанням курсу на сьомому небі лише спекулянти» («112.Україна», 05.03.2014).

Цікаво, що той самий фразеологізм у різний час може мати різні семантичні відтінки та вживатися в абсолютно різних контекстах, пор.: «Або все, або нічого: Президента заставили бігти» (про події, пов'язані з Свромайданом-2014) («АТН», 23.02.2014), «Нова стара Конституція: або все, або нічого» (про конституційну реформу 2012 р.) («Кореспондент», 11.09.2012), «Свро по-нашому: або все, або нічого» (про кваліфікацію до груп футбольного чемпіонату «Свро-2016») («5 канал», 10.0.2016); «Біла ворона сучасного політикуму» (про Дарта Вейдера як кандидата в депутати до Київради), «Біла ворона проти Чорного ворона» (про кандидатів у Президенти Ю. Тимошенко та В. Януковича) («Газета по-українськи», з блогу, 20.07.2016), Шоу з білою вороною на чолі (про перемогу К. Вюрст на пісенному конкурсі «Свробачення-2014») («112.Україна», 10.05.2014) та ін.

Семантична природа фразеологізмів, як відомо, неоднозначна, а інколи навіть суперечлива. Фразеологічні одиниці саме в мові 3МІ можуть мати не тільки усталене, традиційне значення, а й протилежне, що надає медійній мові більшої експресії, пор.: «Кличко дав гарбуза російській стороні: боєць відмовив у поєдинку з Повєткіним» («ZiK», 10.04.2014), «Тимошенківці дaли Турчинову гарбуза: назад до партії приймати одіозного політика вони не хочуть» («День», 10.06.2014), «,Металіст“ отримав гарбуза від Мілевського: 
пропозицію футболіст відхилив, сподіваючись на кращі контракти» («112 канал», 07.08.2015), «Отримати гарбуза від Рудьковського за щастя рейтинговим партіям - політолог» («УНІАН», 10.06.2014).

Отже, фразеологізми у мові ЗМІ можуть виконувати різні функції:

\section{1. Вплив на реципіснта}

Вплив на реципієнта $є$ головною функцією мас-медіа (саме це підтверджує думку сучасних медіалінгвістів про те, що фразеологічні одиниці $є$ універсаліями медійної мови). Вплив на реципієнта може досягатися різними фразеологізмами, як традиційними, так і новими (трансформованими), що виникають відповідно до вимог часу та мають тенденцію активного тиражування соціумом. Саме тому стилістична трансформація можлива тільки тоді, коли ці одиниці відомі широкій аудиторії (ефект непередбачуваності, який вважається основним у медійній комунікації, буде можливий у похідному фразеологізмі лише за умов урахування фонових знань реципієнта): Податки до люстраиії доведуть [трансформація фразеологізма «Язик до Києва доведе» - Д. С.] («Експрес», 10.09.2015), «Поправки до голосування додали велику ложку дьогтю у антикорупційну бочку» («ТСН», 15.07.2016), «Сім раз відміряй-один раз прийми: депутати Верховної ради, не вагаючись, приймають нові закони» [трансформація фразеологізма «Сім раз відміряй один раз відріж» - Д. С.] («Українська правда», 19.09.2016) та ін.

Часто в українських ЗМІ вживаються фразеологізми, значення яких спеціально сплутуються, що надають тексту (чи заголовку тексту) більшої експресивності та емоційності, інколи - навіть іронії. Це, до слова, теж стилістична трансформація, адже сприйняття фразеологізму інше - інколи протилежне, а його семантика - зовсім різниться від основної: «Відкрити Америку»: «перший „пишний“ прийом президента Порошенка» («ZiK, 11.02.2015»), «Віра горами рухає»: «Ульянченко представила новий проект порятунку України» («Факти», 11.06.2015), «Далеко куцому до Зайия»: «як РПЛ виключила зі списку бувалого депутата Івана Зайця» («Експрес», 11.09.2015), «Зірковий час»: «одеський скандал із Лорак набув широкої популярності в Росії» («Факти», 05.08.2014), Розпускати «язык», «або як Рада хоче змінити мовну політику країни» («ТСН», 07.10.2013) та ін.

\section{2. Номінативна функція}

Виконуючи номінативну функцію, фразеологізми у мові ЗМІ називають єдині поняття, явища, якості, стани та ознаки. Тому часто фразеологізми можуть замінюватись синонімічними словами, що в медійній комунікації особливо актуально для опису певних процесів: на кожному кроці - скрізь, всюди: «Патріоти зм на кожному кроці: вулиці столиці стали жовто-блакитними» («Експрес», 10.03.2014); прикусити язика - замовчати: «Прикусити язика політикам дозволив новий антирейтинг найбільш корумпованих депутатів у Верховній Раді» («Факти», 10.09.2015); точка зору - думка: «Цю 
точку зору Гриценка тепер будуть розглядати у суді» («Експрес», 11.11.2016); права рука - помічник: «Права рука Ющенка також серед бомонду «порошенківців» («Експрес», 10.06.2015); книга за сімома печатками - таємниця: «Бюджет-2013 - книга за сімома печатками» («День», 10.10.2016).

\section{3. Посднання «стандарту» та експресії}

Фразеологічні звороти підвищують виразність викладу, його образність і враження, одночасно виконуючи «стандартну» функцію, виступаючи як готові мовні «штампи», типу «чорний день»: «судний день для народу», «чорна (п'ятниця, субота, неділя) для Ради», «чорний день для інвесторів» та ін.; «золоте правило» («золоте правило для бійців», «золоте правило для депутатів», «золоте правило для можновладців»), «бути на коні», «нагрівати ру-

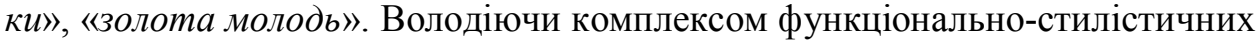
якостей, вони використовуються як постійний «робочий засіб» в різних жанpax - як інформаційних, так і аналітичних. Зауважимо, що в рекламних текстах це одна з головних функцій, що використовується для досягнення впливового ефекту на реципієнта (див. JUCKER 1992: 198): «Влуч у яблучко. Купи Apple» (реклама Apple у «Цитрус. Гаджети та аксесуари»), «Вийти сухим із води? Це легко з NeverWet» (реклама спрея для взуття NeverWet) та ін.

\section{4. Виховна функція}

Саме за допомогою фразеологізмів автор може донести до реципієнта життєві істини, громадянську чи патріотичну позиції. Часто авторами виносяться у заголовки фразеологізми, які носять виховний характер: «Вік живи вік учись: як першокласник обіграв у шахи мера» («Україна молода», 10.10. 2016), «Жити душа в душу, або Один день 3 життя простого подружжя Вокальчуків» («СТБ», 11.04.2015), «Борітеся - поборете: правда про прифронтовий Донбас» («Люди. Hard Talk», 10.03.2016) та ін.

\section{5. Образна функція}

Вона полягає у створенні за допомогою фразеологічних одиниць як фонової лексики медійного тексту цілої картини описового явища. Наприклад, у статті в газеті «Літературна Україна» «Не стало Великого Богдана» (2012р.) (про смерть Богдана Ступки) використано різні фразеологізми для створення образу людини, яку втратило українське мистецтво:

У місті каштанів попрощалися з видатним актором та генієм сценічного мистецтва Богданом Ступкою. Його Сізіфова праия відродити класичний театр у стінах Франка не залишилась не поміченою. Адже золоте правило кожного, хто належав до трупи театру - слугувати мистецтву і жити душа в душу з побратимами, забуваючи про чвари та мистецькі розбрати. Йому не співали $\partial u \phi i-$ рамби в вічі - він це не любив. Він хотів справжньої критики для себе та оточуючих... (зі статті-некролога в газеті «Літературна Україна», 25.07.2012). 


\section{6. Смислово-концептуальна функція}

Важлива роль фразеологізмів відводиться у заголовках, які, фактично, $\epsilon$ смисловим центром медійної статті. Фразеологізми тут виконують смисловоконцептуальну функцію, адже саме заголовок - це сильна, акцентована позиція мас-медіа, бо саме на заголовок в першу чергу звертає увагу реципієнт. Наведемо ілюстративні приклади з заголовків: «Або все, або нічого» (заголовок статті у виданні «Газета.иа» про внесення змін до Конституції щодо повноважень Президента); «Кров з молоком» (заголовок статті у газеті «День» про святкування Дня молоді у столиці); «Яблуко розбрату» (заголовок статті на порталі журнала «Кореспондент» про нову посаду Голову Антикорупційного бюро України), «Як у воду опущена» (заголовок статті з блогу у виданні «УНІАН.Культура» про зрив виступу Ані Лорак в Одесі) та ін.

Окремо варто зазначити про творення / трансформацію медійної фразеології у рекламі, адже рекламні тексти є унікальним матеріалом для дослідження функціонування мовних механізмів комунікативних стратегій, тактик, різного роду функцій. Фразеологія реклами, що володіє позитивною (для реклами негативну чи нейтральну в аналізованих текстах ми не виявили) оцінною семантикою, експресивно уточнює візуальний образ предмету реклами та може виступати в якості суттєвого переконливого аргументу.

У рекламній комунікації, таким чином, фразеологізм розуміється як певна структурно стала експресивна одиниця, що надає мас-медійному тексту додаткової емоційності. Рекламний фразеологізм, відтак, є однією з найяскравіших і дієвих мовних одиниць в advertising communication, метою використання якого (фразеологізму) $\epsilon$ емоційний вплив на реципієнта. У рекламі та піар-сфері саме фразеологізми можуть бути основою для т. зв. «рекламного гіпнозу» та масово впливати на потенційного покупця: «Лови момент! Купуй шубу!» (реклама магазину «Роксан. Галерея шуб та хутра»), «Як смачно влучити у яблучко» (реклама соку «Садочок»), «І вийдеш сухим із води» (реклама смарт-годинника Samsung Galaxy Gear) та ін. А переосмислений фразеологізм, що може розпадатися на окремі семантичні складники, інколи набуває нових смислів та спонукає споживачів до активних дій: «Rich. Життя прекрасне. Як не крути!»; «Raptor. I комар носа не підточить»; «Свіже рішення від „Mentos“»; «Керуй мрією. Toyota Corolla» та ін.

Фразеологія як стилістично маркована мовна універсалія у рекламних текстах дозволяє навіть на відстані з реципієнтом висловити емоції (позитивні /негативні), а створення образу через фразеологізм допомагає оцінити рекламний продукт із погляду симпатії / антипатії: «Шампунь Elseve. Коли волосся втрачає силу»; «Тide. І прання під домашнім арештом»; «ІмперіалБанк. Він - Альфа і Омега» та ін.

Фразеологія часто включається в контекст слоганів (спостерігаємо це в теле- та радіодискурсах), або ж навіть $є$ структурно слоганами-фразеологізмами: Кров з молоком (слоган телеканалу «М1»), Бачити серием (слоган 
телеканалу «Україну»), Ти не один (слоган телеканалу «1+1»), Живи музикою (слоган радіостанції «Люкс-FM»), Все краще - повертається (слоган радіостанції «Мелодія») та ін.

Ефективним вважаємо і творення нових фразеологізмів (або ж 3 переосмисленням / трансформацією значень) у рекламі: золотий вік (ювелірний) (з реклами «КЮЗ»), золотий час (цінний, актуальний, важливий) (з реклами банку «Аваль»), сталевий характер (з реклами «Gillette») та ін. Щоправда, не кожен фразеологізм може бути вдалим і розтиражованим у подальших текстах. У рекламі за допомогою фразеології найбільше створюється каламбурів та «гри слів» як стилістичних прийомів: «Reebook. Будь у формі»; «Redbull. Надає крила»; «Ренні. Швидка допомога вашому шлунку»; «Шампунь для волосся PantenePRO-V. Блискучий результат» та ін.

Семантична структура фразеологізма в рекламі побудована за ієрархічним принципом: усе смислове навантаження фразеологізм бере на себе. Саме тому у рекламних слоганах ми зустрічаємо фразеологізми без пояснення. Реципієнт розуміє широку семантику фразеологізма лише, зрозумівши, якої торгової марки вона стосується: хвилинна справа (слоган медичного препарату «Мікролакс»), легка на підйом (слоган авіакомпанії «Windrose»), справа на мільйон (слоган лотереї «Лото-Забава»), тримай хвилю (слоган аквапарку «DreamIsland») та ін. У сучасній телевізійній рекламі інколи вдаються до парафразів як стилістичних прийомів, що наближаються за структурою та семантикою неподільності до фразеологічних інновацій. Тут наголосимо на використанні цього стилістичного прийому як найбільш ефективного на телебаченні та радіо, акцентуючи на широкій стилістичній трансформації: Любов з першої... ложки («Мівіна»), В житті завжди є місие... техніці («Comfy»), Кохання з «першого» депозиту («Аваль») та ін.

Отже, роль використання фразеологізмів у ЗМІ (на радіо, телебаченні, рекламі, в газетах та журналах) має велику практику. Це пояснюється прагненням авторів надати текстам особливий національний колорит, реалізувати потенційну здатність фразеологізмів актуалізувати активну позицію в тексті та емоційно впливати на реципієнта. Функції фразеологізмів у мас-медіа, як бачимо, дуже широкі та сприяють головним завданням 3МI, що успішно виконуються за допомогою цих мовних засобів, - інформувати та впливати.

\section{6. Висновки та перспективи дослідження}

Метафоричність, конотативність, експресивність, емоційне навантаження - усі ці характеристики фразеологічних одиниць надають мові 3МI образності та виразності, а сам фразеологізм у медійній мові набуває нових відтінків у значенні й може активно використовуватися як із прямою, так і з трансформованою семантикою.

Аналіз сучасних мас-медійних текстів України показав, що використання фразеологізмів у ЗМІ має велику практику. Це пояснюється прагненням авторів надати текстам особливий національний колорит, реалізувати потен- 
ційну здатність фразеологізмів актуалізувати активну позицію в тексті й емоційно впливати на реципієнта. Виконуючи різні стилістичні функції, фразеологізми в українському медіапросторі надають мові великої емоційності та впливають як на індивідуальну, так і на масову свідомість реципієнта/реципієнтів. Фразеологізми у медіакомунікації здебільшого виконують маніпулятивну функцію та функцію впливу, відзначаючись яскравими емоційними можливостями, що впливають на реципієнта і виступають в якості стилістичного засобу. Фразеологізми як вербальні коди нації та маркери національного менталітету й культури здатні створювати вербальний образ зображуваного явища.

Найчастіше фразеологічні одиниці в українських медійних текстах вербалізують актуальні питання сучасності, вони можуть використовуватися як у самих текстах, так і в заголовках (або підзаголовкових частинах - в друкованій пресі; в ехо-фразах - в рекламі; в промороликах - на радіо та телебаченні тощо). I в першому, і в другому випадках вживання фразеологізмів у структурі медіатекстів має позитивне значення на розвиток медійного дискурсу в цілому, адже саме фразеологія надає різноманітності мові 3MI, а фразеологічна трансформація - образності та символізму.

Перспективним вважаємо аналіз стратегій та тактик, що використовуються у ЗМІ для підсилення емоційності та впливу на реципієнта саме за допомогою медіафразем. Також продовжуємо працювати над аналізом стилістичних функцій нових фразеологічних одиниць у різних сферах масової комунікації, зокрема рекламі, соціальних мережах, PR- та HR-сферах. Саме медіалінгвістичний аналіз нової фразеології дозволяє прослідкувати тенденцію функціонування неофразем як мовних універсалій медіакомунікації, що виникають в масовій свідомості та виступають певним «дзеркалом» суспільно-політичного життя України/світу.

\section{Література}

БОГОЛЕБСКА $2010=$ БОГОЛЕБСКА Б. Стиль, дискурс, медиа. Лодзь, 2010.

Винокур 1959 = Винокур Г. Избранные труды по русскому языку. Москва, 1959.

ГАЙдА $2015=$ ГАЙдА С. Актуальные задачи стилистики. Актуальные проблемы стилистики 1 (2015): 11-22.

ДОБРОСКЛОНСКАЯ 2008 = ДОБРОСКЛОНСКАЯ Т. Медиалингвистика. Системный подход к изучению языка СМИ. Москва, 2008.

ДусКАЕВА $2010=$ ДускАЕВА Л. Лексические инновации языка СМИ. В кн.: ДуСКАEBA Л. Стилистика медиатекста. Санкт-Петербург, 2010. 134-145.

КвІт 2008 = КвІт С. Масові комунікації. Київ, 2008. 180-185.

ПочеПцов $2008=$ ПочеПцов Г. Інформаційна політика. Київ, 2008.

Сизонов 2015a = Сизонов Д. Медицинская терминология в белорусских, польских, русских и украинских медиа. Семантико-стилистическая характеристика. Stylistyka 24 (2015): 271-281.

Сизонов $2015 \mathrm{~b}=$ Сизонов Д. Современная медийная фразеология в украинских СМИ: стилистический анализ. Медиалингвистика 2015/4: 97-108. 
Стишов 2003 = Стишов О. Украӥнська лексика кіния XX століття (на матеріалі засобів масової інформачіі). Київ, 2003.

ТАРАНЕНКО 2002 = ТАРАНЕНКО О. Колоквіалізація, субстандартизація та вульгаризація як характерні явища стилістики сучасної української мови (з кінця 1980-х рр.). Мовознавство 2002/4-5: 33-39.

Чудинов $2010=$ Чудинов А. Политическая лингвистика. Москва, 2010. 140-143.

ШЕВченко 2001 = ШЕвчЕнко Л. Інтелектуальна еволюиія української літературної мови. Теорія аналізу. Київ, 2001.

ШЕВЧЕНКО 2014 = ШЕВЧЕнко Л. (ред.) Медіалінгвістика. Словник термінів і понять. Київ, 2014.

DZIEWoŃSKA-KISS-RÁDUly 2014 = DZIEwoŃSKA-Kiss Dorota, RÁDUly Zsuzsanna: Obraz anioła w polskiej i węgierskiej frazeologii. Studia Slavica Hung. 59 (2014): 307-312.

JuCKER 1992 = JuCKer Andreas H. Social Stylistics. Syntactic Variation in British Newspapers. Berlin, 1992.

PERrIN $2006=$ PERrin D. Medienlinguistik. Konstanz, 2006.

WorsowICZ 2013 = WorsowICZ M. O «duchu stosowności». Teoria retoryczna a wspótczesna praktyka medialna. Łódź, 2013. 